\title{
Penerapaan Pendekatan Taktis dan Gaya Mengajar Tugas dalam Pembelajaran Futsal
}

\section{Rivaldy Kusuma Wardana}

Program Studi Pendidikan Guru Sekolah Dasar Pendidikan Jasmani, Universitas Pendidikan Indonesia

\begin{tabular}{|c|c|}
\hline Info Artikel & Abstrak \\
\hline $\begin{array}{l}\text { SejarahArtikel: } \\
\text { Diterima Januari } 2018 \\
\text { Disetujui April } 2019 \\
\text { Dipublikasikan Mei } 2019\end{array}$ & $\begin{array}{l}\text { Penelitian ini bertujuan untuk mengetahui peningkatan keterampilan bermain } \\
\text { futsal siswa melalui penerapaan pendekatan taktis dan gaya mengajar tugas. } \\
\text { Penelitian ini menggunakan metode penelitian tindakan kelas dengan pen- } \\
\text { dekatan kuantitatif. Instrumen yang digunakan yaitu lembar observasi dan } \\
\text { melakukan penilaian pada saat pembelajaran berlangsung dengan sampel } \\
\text { sebanyak } 32 \text { siswa. Hasil penelitian menunjukkan keterampilan bermain } \\
\text { siswa meningkat yang terlihat dari pretest }(31 \% \text {, ) siklus } 1 \text { tindakan } 1 \text { ( } 46 \%) \text {, } \\
\text { siklus } 1 \text { tindakan } 2(56 \%) \text {, siklus } 2 \text { tindakan } 1 \text { (65\%) dan siklus } 2 \text { tindakan } 2 \\
\text { ( } 81 \%) \text {. Dari hasil data tersebut dapat disimpulkan bahwa penerapan pendeka- } \\
\text { tan taktis dan gaya mengajar tugas dapat meningkatkan keterampilan bermain } \\
\text { futsal siswa. } \\
\text { Abstract } \\
\text { The aim of the research was to find out the improvement of students games } \\
\text { performance by using of tactical approaches and practice sytle on futsal } \\
\text { learning. It's used class action research. The instrument used were the obser- } \\
\text { vation sheet and assessing students during learning with a sample of } 32 \text { stu- } \\
\text { dents. The result of research shows that students games performance in- } \\
\text { creased that can be seen from the pretest (31\%). Cycle I action } 1 \text { (46\%), cycle } \\
\text { I action } 2 \text { (56\%), cycle } 2 \text { action } 1 \text { (65\%), and cycle } 2 \text { action } 2 \text { (81\%). The re- } \\
\text { sults shows that the application of tactical approaches and practice style im- } \\
\text { prove students'games performance on futsal. }\end{array}$ \\
\hline
\end{tabular}




\section{PENDAHULUAN}

Dalam kurikulum 2013 untuk mata pelajaran pendidikan jasmani, olahraga dan kesehatan SD tertulis, bahwa ruang lingkup pembelajarannya meliputi enam aktivitas, yaitu aktivitas Pola Gerak Dasar, aktivitas permainan dan olahraga, aktivitas kebugaran, aktivitas senam, aktivitas ritmik dan aktivitas aquatik (Permendikbud, 2014).

Berdasarkan uruaian di atas masingmasing aktivitas,memiliki karakteristik gerak yang disesuaikan dengan kebutuhan anak diantaranya bahwa semua aktivitas tersebut memiliki beberapa jenis cabang olahraga yang populer dimasyarakat dewasa ini. Sebagai contoh, aktivitas permainan dan olahraga, berisi cabang-cabang yang belum terwakili dalam aktivitas yang dimaksud di atas, di dalamnya terdapat cabang olahraga permainan dan olahraga seperti cabang olahraga atletik, serta beladiri.

Aktivitas permainan mewakili banyak cabang olahraga permainan yang popular dimasyarakat, dari mulai sepak bola, voli, basket dan futsal bahkan termasuk cabang olahraga seperti pingpong/tenis meja, bulutangkis dan kasti. Namun demikian mengingat banyaknya jenis cabang olahraga permainan yang banyak disesuaikan dimasyarakat, dalam kurikulum 2013 juga mencoba mengakomodasinya dengan cara mengelompokan aktivitas permainan tersebut ke dalam 2 kelompok besar, yaitu, permainan bola besar dan permainan bola kecil. Permainan bola besar adalah permainan yang menggunakan bola besar di dalam permainan bola ada beberapa cabang olahraga seperti, sepak bola, bola basket, bola voli, futsal dan bola tangan. Sedangkan permainan bola kecil relatif menggunakan bola kecil ada beberapa dalam permainan bola kecil seperti, tenis meja, tenis lapang, bulu tangkis dan kasti (Permendikbud, 2014).

Naskah ini mengangkat pembelajaran futsal dalam pendidikan jasmani, sebagaimana terkait dari pengelompokan permamainan diatas, futsal termasuk ke dalam kelompok bola besar. Futsal adalah permainan dua regu, masing-masing regu terdiri dari lima orang, termasuk salah satunya penjaga gawang (Sumpena, 2017). Tujuan permainan futsal sama dengan permainan sepak bola, yaitu memasukan bola ke gawang lawan sebanyak-banyaknya dan mempertahankan gawangnya agar tidak kemasukan. Futsal juga disebut sebagai olahraga dinamis, dimana para pemainnya dituntut untuk selalu bergerak dan dibutuhkan keterampilan teknik yang baik serta mempunyai determinasi tinggi. Teknik dasar pada permainan futsal sama dengan permainan sepak bola, yaitu kicking, passing, stoping, dribling, heading, tackling, goal keeping (Sucipto, 2015). Berdasarkan uraian tersebut, permainan futsal adalah permainan beregu yang hampir sama dengan permainan sepak bola hanya saja permainan futsal dimainkan oleh lima lawan lima dan lapangan yang kecil sedangkan permainan sepak bola dimainkan oleh sebelas lawan sebelas dan lapangan yang besar.

Sebagaimana pembelajaran permainan lainnya, pembelajaran futsal di sekolah perlu diajarkan kepada siswa dengan menggunakan pendekatan yang tepat. Sejauh ini pendekatan yang banyak diajarkan untuk di sekolah dalam pembelajaran permainan di sekolah adalah pendekatan teknis, maka dari itu penulis ingin men- 
erapkan pendekatan taktis dalam pembelajaran permainan.

Pendekatan taktis dalam pengajaran permainan adalah untuk meningkatkan pemahaman siswa terhadap konsep bermain. Melalui pendekatan taktis, siswa didorong untuk memecahkan masalah taktis dalam permainan (Mitchell, \& Griffin, 2003). Masalah taktis pada hakikatnya adalah penerapan keterampilan teknik yang tepat dalam situasi permainan. Dengan menggunakan pendekatan taktis, siswa semakin memahami keterkaitan antara teknik dan taktik dalam suatu permainan. Dengan menerapkan pendekatan taktis, diharapkan dapat meningkatkan mutu pembelajaran cabang olahraga di sekolah.

Pendekatan taktis pada dasar nya bertujuan agar siswa mampu memadukan penguasaan teknik dasar yang dipelajari dengan kemampuan bermainnya serta sekaligus menanamkan keyakinan dalam diri siswa untuk dapat menerapkan taktik bermainnya sejalan dengan meningkatnya keterampilan yang dimilikinya (Sucipto, 2015).

Pendekatan teknis dalam mengajarkan suatu cabang olahraga permainan. Artinya, menitik beratkan pada penguasaan teknik dasar kecabangan dan kurang mementingkan kemampuan pemahaman siswa terhadap hakekat dari permainan itu sendiri. Penerapan pendekatan teknis akan menyulitkan siswa dalam memahami makna permainan dalam suatu cabang olahraga, dampaknya siswa tidak tertarik pada proses pembelajaran. Suasana yang kurang menyenangkan dan menggembirakan tersebut akan membuat siswa kurang termotivasi dalam mengikuti pembelajaran pendidikan jasmani di sekolah (Sucipto, 2015).
Sebagaimana pembalajaran permainan lainnya, pembelajaran futsal di sekolah memerlukan gaya mengajar yang tepat. Sejauh ini mayoritas guru penjas menggunakan gaya komando. Maka dari itu diperlukan penerapan gaya mengajar baru agar terdapat berbagai variasi gaya mengajar. Salah satunya gaya mengajar tugas atau praktek. Gaya mengajar praktek atau tugas adalah gaya mengajar yang memberikan sedikit kebebasan kepada siswa untuk membuat keputusan (Mosston, 1994) . Gaya ini memberikan siswa untuk berlatih secara individu dan mandiri, serta menyediakan guru waktu untuk memberikan umpan balik feedback kepada siswa secara individu dan pribadi. Dalam gaya tugas ada beberapa keputusan selama pertemuan berlangsung yang dipindahkan dari guru ke siswa. Pergeseran keputusan ini memberi peranan dan perangkat tanggung jawab baru kepada siswa.

Gaya mengajar tugas memungkinkan anak untuk mengambil keputusan tentang kapan, berapa lama, berapa kali, serta kapan mengakhiri tugas yang diberikan guru. Cirinya adalah, satu stimulus dari guru, respon siswa tidak terbatas. Guru memberikan umpan balik secara langsung kepada peserta didik selama proses pelaksanaan tugas berlangsung. Peserta didik dapat diorganisir secara perorangan, berpasangan, berkelompok, maupun klasikal dalam melaksanakan tugas/latihan. Gaya mengajar tugas ditempuh oleh guru untuk mengubah gaya mengajar tugas yang selama ini selalu guru yang berperan. Persoalan pada pembelajaran permainan yang diajarkan menggunakan gaya mengajar komando selalu menyisakan masalah, dianataranya banyaknya anak yang sering hilang kemandiriannya dan sangat bergantung 
pada guru sehingga gaya komando sering mematikan motivasi siswa (Sucipto, 2019). Berdasarkan uraian tersebut, tujuan penelitian ini adalah untuk mengetahui bagaimana penerapan pendekatan taktis dan gaya mengajar tugas dalam pembelajaran futsal.

\section{METODE PENELITIAN}

Metode yang digunakan dalam penelitian ini adalah metode kualitatif dengan rencana penelitian tindakan kelas. Penelitian ini terdiri dari empat tahapan yaitu : perencanaan, pelaksanaan tindakan, pengamatan dan refleksi. Penelitian tindakan kelas ini bertujuan untuk mengetahui apakah penerapan model pembelajaran pendekatan taktis berpengaruh dalam proses pembelajaran permainan futsal.

Lokasi atau tempat penelitian dilaksanakan di SDN 032 Tilil Kota Bandung Subjek penelitian dalam PTK ini adalah siswa kelas IV (Empat) SDN 032 Tilil Kota Bandung. yang berjumlah 32 siswa dengan 16 siswa lakilaki dan 16 siswi perempuan. Peserta didik di Sekolah ini berasal dari latar belakang keluarga yang berbeda-beda, orang tua mereka berasal dari profesi yang berbeda-beda pula, ada yang berprofesi sebagai pedagang, buruh tani, guru, karyawan, dan lain-lain.

Prosedur penelitian ini terdiri dai 2 siklus yang setiap siklusnya terdapat dua tindakan. Berdasarkan hasil pengamatan dan observasi awal (pra-siklus), ditemukan bahwa tindakan yang bertujuan untuk meningkatkan keterampilan bermain melalui permainan futsal.

Rencana yang dilakukan dalam penelitian ini menggunakan model desain arikunto. Konsep pokok penelitian model desain Arikunto terdiri dari empat komponen yaitu perencanaan (planning). Tindakan (action), pengamatan (observation), dan Refleksi (reflecting). Adapun teknik pengumpulan data yang digunakan oleh peneliti yaitu: observasi, catatan lapangan, dan dokumentasi. Analisis data yang dikumpulkan pada setiap kegiatan observasi dari pelaksanaan siklus penelitian memakai analisis kuantitatif karena berupa angka-angka menggunakan presentase untuk melihat kecenderungan yang terjadi dalam proses kegiatan pembelajaran. Proses analisis dimulai dari awal sampai akhir pelaksanaan tindakan. Data yang terkumpul dapat dianalisis dari tahap akhir dalam pelaksanaan tindakan dengan disesuaikan pada karakteristik, fokus masalah, serta tujuan. Lembar observasi keterampilan bermain futsal menjadi rujukan penilaian dari kemajuan belajar siswa.

\section{HASIL PENELITIAN}

\section{Pada Pra Observasi}

Tahap pelaksanaan tindakan penelitian merupakan implementasi dari serangkaian perencanaan yang telah disusun untuk mencari solusi dan mengurangi kesulitan peserta didik dalam melaksanakan pembelajaran yang diberikan oleh guru. Sebelum merencanakan penelitian tindakan kelas (PTK), peneliti harus terlebih dahulu mengetahui serta memahami deskripsi masalah pembelajaran yang menjadi hambatan peserta didik dalam proses pembelajaran serta untuk dicarikan solusi dari permasalahan tersebut. Oleh karena itu, sebelum merencanakan dan melakukan tindakan peneliti melakukan observasi awal terlebih dahulu. Tujuan dari diadakannya tahap observasi awal ini antara lain untuk: 
- Mengetahui faktor yang menjadi penghambat peserta didik dalam pembelajaran aktivitas futsal di SDN 032 Tilil Kota Bandung, sehingga peneliti dapat mengidentifikasikan masalah yang terjadi kemudian dicarikan solusi dari masalah tersebut.

- Melihat tingkat keberhasilan awal peserta didik dalam pembelajaran permainan futsal terhadap keterampilan bermain dengan menggunakan pendekatan taktis dan gaya mengajar tugas yang melakukan melalui langkah pre-test, sebagai gambaran awal untuk menentukan tindakan yang akan dilakukan pada tahap pelaksanaan pembelajaran selanjutnya.

- Mengetahui sejauh mana siswa melakukan keterampilan bermain yang dapat dibangun oleh peserta didik dalam proses pembelajaran pada kegiatan pembelajaran aktivitas futsal.

Kegiatan pembelajaran pendidikan jasmani di SD Negeri 032 Tilil Kota Bandung untuk kelas IV yang dijadikan sampel penelitian dengan jumlah 32 peserta didik (14 perempuan dan 18 laki-laki) dilaksanakan dengan alokasi waktu $2 \times 35$ menit setiap pertemuan. Dengan fasilitas yang memadai seperti lapangan olahraga, kones, bola, dan lain sebagainya guna menunjang pembelajaran pendidikan jasmani berjalan dengan lancar disekolah. Setelah seluruh data terkumpul, maka langkah selanjutnya adalah menganalisis serta mengolah data tersebut.

\section{Pelaksanaan (Siklus I Tindakan I)}

Pada tahap ini kegiatan yang dilaksanakan berdasarkan perencanaan tindakan yang telah ditetapkan Fokus dalam pembelaja- ran ini adalah meningkatkan keterampilan bermain dalam aspek keputusan yang diambil, melaksanakan keterampilan, dan memberi dukungan dalam pembelajaran futsal 3 vs 1 dan 2 vs 1 Pembelajaran dilakukan pada hari selasa tanggal 7 Agustus 2018 mulai pukul 07.00 s/d 09.00 WIB di lapangan SDN 032 Tilil Kota Bandung.

Dari hasil pengamatan atau penilaian selama siklus satu tindakan satu dengan persentase variabel terhadap keterampilan bermain dalam aspek keputusan yang diambil, melaksanakan keterampilan, dan memberi dukungan dalam pembelajaran futsal adalah sebagai berikut: hasil penilaian siklus 1 tindakan 1, peneliti menemukan bahwa sebagian siswa masih kurang memperhatikan dan masih kesulitan dalam melakukan permainan futsal. Pada permainan 3 vs 1 dan 2 vs 1 siswa yang bertugas sebagai penyerang masih kesulitan dalam keterampilan bermain, selain itu bola sering direbut oleh lawan dan kurang membuka ruang saat dijaga lawan. Akan tetapi hasil belajar siswa sedikit meningkat dalam aspek keputusan yang diambil melaksanakan keterampilan, dan memberi dukungan. Hal demikian dapat kita lihat dari naiknya nilai persentase menjadi $46 \%$.

Dari hasil refleksi memperlihatkan adanya peningkatan dari hasil pembelajaran futsal terhadap keterampilan bermain pada saat pembelajaran berlangsung ditunjukkan oleh peserta didik pada tahap observasi awal dengan pelaksanaan siklus 1 tindakan 1 yang dilakukan oleh peneliti dengan menerapkan model pembelajaran pendekatan taktis dan gaya mengajar tugas. Peningkatan tersebut ditunjukkan oleh naiknya jumlah presentase yang berhasil didapatkan dalam proses pembelajaran futsal, 
baik terhadap keterapilan bermain pada saat pembelajaran berlangsung yang berhasil didapatkan dari jumlah sebelumnya $31 \%$ menjadi 46\%.Pada pelaksanaan siklus 1 tindakan 1 ini proses serta prestasi belajar peserta didik pada pembelajaran futsal dikategorikan masih kurang baik berdasarkan catatan lapangan dan presentase komponen penampilan bermain yang dicapai dengan jumlah kurang dari $75 \%$. Maka dari itu perlu adanya tindakan selanjutnya guna memperbaiki proses dan hasil belajar peserta didik.

\section{Pelaksanaan (Siklus I Tindakan 2)}

Pada tahap ini kegiatan yang dilaksanakan herdasarkan perencanaan tindakan yang telah ditetapkan. Fokus dalam pembelajaran ini adalah meningkatkan keterampilan bermain dalam aspek keputusan diambil melaksanakan keterampilan. dan memberi dukungan dalam permainan kucing bola dan 3 vs 3. Pembelajaran dilakukan pada hari selasa tanggal 14 agustus 2018 mulai pukul $07.00 \mathrm{~s} / \mathrm{d}$ 09.00 WIB di lapangan SDN 032 Tilil Kota Bandung.

Hasil penilaian siklus 1 tindakan 2 peneliti menemukan bahwa sebagan siswa masih kesulitan dalam melakukan gerakan dribbling kicking dan stoping dan siswa yang menjadi penyerang sering terebut bolanya oleh tim bertahan. Akan tetapi hasi belajar sebagian siswa meningkat dalam aspek keputusan vang diambil, melaksanakan keterampilan, dan memberi dukungan Hal demikian dapat kita lihat dari naiknya nilai persentase dari $46 \%$ menjadi $56 \%$.

Sementara berdasarkan catatan lapangan pada pelaksanaan siklus 1 tindakan 2 proses pembelajaran menunjukkan perkembangan lumayan baik. Dimulai dari pembukaan kelas peserta didik sudah memperlihakan sedikit antusian mereka untuk memulai pembelajaran futsal, ketika kegiatan pembelajaran berlangsung peserta didik masih ada yang jenuh dan kurang aktif bergerak melakukan tugas gerak yang telah diberikan sesuai dengan diberikan materi oleh guru. Peserta didik terus mencoba dan berlatih melakukan keterampilan bermain futsal sesuai teknik-teknik yang diberikan oleh guru.

Adapun dari hasil refleksi memperlihatkan adanya peningkatan dari hasil penelitian pada tahap pre-test dan pelaksanaan siklus 1 tindakan 1, hingga pelaksanaan pada siklus 1 tindakan 2. Pada tahap pelaksanaan siklus 1 tindakan 2 ini proses pembelajaran sudah cukup membaik, hal ini ditunjukkan dengan presentase hasil belajar keterampilan bermain yang ditunjukkan peserta didik yang naik dari pelaksanaan pada siklus 1 tindakan 1 sebelumnya sebesar $31 \%$ menjadi $46 \%$. Serta presentase terhadap hasil keterampilan bermain $56 \%$. Pada pertemuan siklus 1 tindakan 2 ini proses serta prestasi belajar peserta didik pada pembelajaran permainan futsal dikategorikan masih kurang baik berdasarkan catatan lapangan dan presentase hasil belajar yang dicapai dengan jumlah kurang dari 75\%. Oleh sabab itu, peneliti dan observer sependapat untuk melanjutkan penelitian pada tahap selanjutnya guna memperbaiki proses pembelajaran serta meningkatkan keterampilan bermain peserta didik. 


\section{Pelaksanaan (Siklus II tindakan 1)}

Pada tahap ini kegiatan yang dilaksanakan berdasarkan perencanaan tindakan yang telah ditetapkan. Fokus dalam pembelajaran ini adalah meningkatkan keterampilan bermain dalam aspek keputusan yang diambil, melaksanakan keterampilan dan memberi dukungan dalam permainan 4 vs 3 Pembelajaran dilakukan pada hari selasa tanggal 21 agustus 2018 mulai pukul $07.00 \mathrm{~s} / \mathrm{d}$ 09.00 WIB di lapangan SDN 032 Tilil Kota Bandung.

Hasil penilaian siklus 2 tindakan 1, peneliti menemukan bahwa sebagian siswa sudah mengalami peningkatan dalam keterampilan bermain futsal. Namun pada permainan 5 vs 3 dan 5 vs 4 masih ada yang menendang bola tidak terarah pada sasarannya. Tetapi adapula siswa yang hasil belajarnya sudah meningkat dalam aspek keputusan yang diambil, melaksanakan keterampilan, dan memberi dukungan. Hal demikian dapat kita lihat dari naiknya nilai persentase dari $56 \%$ menjadi $65 \%$.

Sementara berdasarkan catatan lapangan pada pelaksanaan siklus 2 tindakan 1 proses pembelajaran menunjukkan perkembangan yang baik. Dimulai dari pembukaan kelas peserta didik sudah memperlihakan antusias mereka untuk memulai pembelajaran futsal, ketika kegiatan pembelajaran berlangsung peserta didik tidak menunjukkan kejenuhan dan tetap aktif bergerak melakukan tugas gerak yang telah diberikan sesuai dengan diberikan materi oleh guru. Peserta didik terus mencoba dan berlatih melakukan keterampilan bermain futsal sesuai teknik-teknik yang diberikan oleh guru. memperlihatkan adanya peningkatan dari hasil penelitian pada setiap tahapnya. Pada tahap pelaksanaan siklus 2 tindakan 1 ini proses pembelajaran sudah membaik, hal ini ditunjukkan dengan presentase hasil belajar terhadap nilai kerjasama yang ditunjukkan peserta didik yang naik dari pelaksanaan pada siklus 1 tindakan 2 sebelumnya sebesar 56\% menjadi 65\%. Dari hasil komponen penampilan bermain pada saat pembelajaran berlangsung.

Adapun perubahan terhadap jalannya proses pembelajaran pada setiap tindakan dari siklus yang peneliti lakukan mengalami perbaikan-perbaikan, baik terhadap proses pembelajaran peserta didik dalam mempelajari materi pemnelajaran permainan futsal. Pada pelaksanaan siklus 2 tindakan 1 ini keterampilan bermain peserta didik dalam pembelajaran permainan futsal dikategorikan sudah baik berdasarkan presentase komponen penampilan bermain yang dicapai dengan jumlah $65 \%$.

\section{Pelaksanaan (Siklus Il tindakan 2)}

Pada tahap ini kegiatan yang dilaksanakan berdasarkan perencanaan tindakan yang telah ditetapkan. Fokus dalam pembelajaran ini adalah meningkatkan keterampilan bermain dalam aspek keputusan yang diambil melaksanakan keterampilan, dan memberi dukungan dalam permainan 5 vs 4 dan 5 vs 5 Pembelajaran dilakukan pada hari selasa tanggal 28 agustus mulai pukul $07.00 \mathrm{~s} / \mathrm{d} 09.00$ WIB di lapangan SDN 032 Tilil Kota Bandung.

Hasil observasi penilaian siklus 2 tindakan 2, peneliti menemukan bahwa hasil belajar siswa sudah mengalami peningkatan dalam keterampilan bermain futsal. Hasil belajar yang diperoleh sudah tercapai, siswa sudah menguasai keterampilan bermain dalam aspek keputusan yang diambil, melaksanakan keterampilan, dan memberi dukungan. Terlihat dari be- 
berapa siswa sudah bias menguasai keterampilan bermain. Hal demikian dapat kita lihat dari naiknya nilai persentase dari $65 \%$ menjadi $81 \%$.

Sementara berdasarkan catatan lapangan pada pelaksanaan siklus 2 tindakan 2 proses pembelajaran menunjukkan perkembangan yang baik. Dimulai dari pembukaan kelas peserta didik sudah memperlihakan antusias mereka untuk memulai pembelajaran futsal, ketika kegiatan pembelajaran berlangsung peserta didik tidak menunjukkan kejenuhan dan tetap aktif bergerak melakukan tugas gerak yang telah diberikan sesuai dengan diberikan materi oleh guru. Peserta didik terus mencoba dan berlatih melakukan keterampilan bermain futsal sesuai teknik-teknik yang diberikan oleh guru.

Hasil data yang diperoleh dari hasil observasi oleh observer langkah selanjutnya yang penulis lakukan adalah melakukan diskusi antara penulis dengan observer, yaitu untuk mengungkapkan hasil temuan selama proses pembelajaran, terutama yang menjadi kendala sehingga hasil tidak maksimal serta mencari solusi sebagai alternative pemecahan masalah untuk mencapai target yang diharapkan. Hasil diskusi yang didapat yaitu hasil dari pendekatan taktis dan gaya mengajar praktek (practice style) sudah mengalami peningkatan melalui aktivitas pembelajaran futsal Terlihat dari terarahnya operan bola siswa kepada temannya dan tepat pada sasarannya.

Pendekatan taktis dan gaya mengajar praktek (pratice style) sudah mengalami peningkatan melalui aktivitas pembelajaran futsal. Terlihat dari terarahnya keterampilan bermain siswa.

Pada tahap pelaksanaan siklus 2 tindakan 2 kali ini presentase yang didapatkan terhadap keterampilan bermain futsal maupun nilai kerjasama yang ditunjukkan oleh peserta didik mengalami peningkatan yang baik. Jika dibandingkan dengan tahap observasi awal, presentase komponen penampilan bermain peserta didik sangat meningkat. sementara pada pelaksanaan siklus 2 tindakan 2 meningkat menjadi $81 \%$. Adapun terhadap presentase keterampilan bermain futsal yang didapatkan peserta didik pada tahap pre-test sebelumnya sebesar $31 \%$ meningkat menjadi $81 \%$ pada pelaksanaan siklus 2 tindakan 2. Pada pertemuan pembelajaran yang telah dilaksanakan sebelumnya peneliti hanya memilih keterampilan bermain futsal yang dipraktikkan secara individu oleh masing-masing peserta didik dalam kelompok, maka dari itu peneliti dan observer sependapat untuk tidak melanjutkan penelitian selanjutnya karena sudah sesuai keinginan.

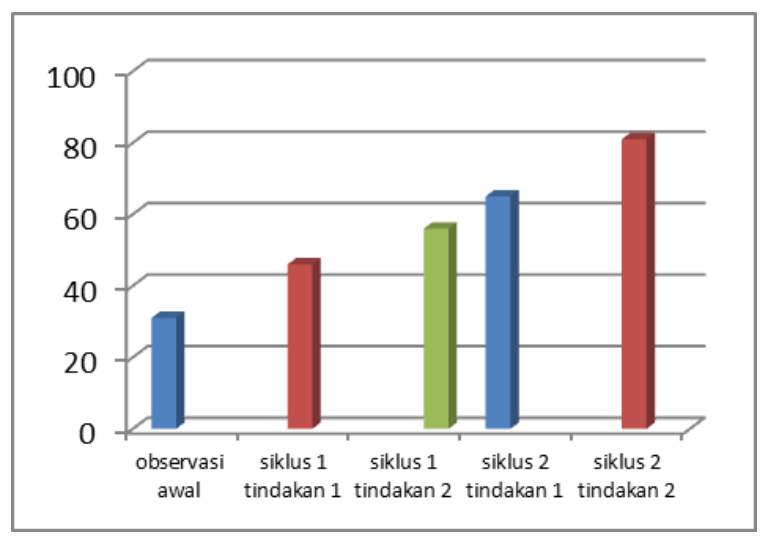

Gambar 1. Komponen Penampilan Bermain dalam

Dari grafik diatas bahwa setiap siklus dan tindakan ada peningkatan terhadap keterampilan bermain siswa, siswa semakin memahami permainan futsal ketika di setiap tindakan dijelaskan. Dari pretes sampai siklus 2 tindakan 2 peningkatan siswa $81 \%$. 


\section{PEMBAHASAN}

Dari pelaksanaan tindakan-tindakan yang telah dilakukan oleh peneliti dalam proses pembelajaran futsal dengan menerapkan pendekatan taktis dan gaya mengajar tugas (practice style), maka hasil yang dapat dicapai oleh guru maupun peserta didik adalah sebagai berikut:

\section{Hasil Pendekatan Taktis dan Gaya Mengajar Tugas dalam Pembelajaran Futsal pada Siklus 1 Tindakan}

Dengan menggunakan pendekatan taktis dan gaya mengajar tugas dalam pembelajaran permainan futsal berpengaruh positif terhadap aspek jasmani peserta didik, namun juga dapat berpengaruh terhadap meningkatnya nketerampilan bermain yang dibangun oleh masingmasing individu. Dapat dilihat dalam siklus 1 tindakan 1 ini meningkat keterampilan bermain pembelajaran futsal peserta didik dari hasil pretest presentase nilai keterampilan bermain peserta didik yaitu $31 \%$ dapat meningkat menjadi $46 \%$, memang peningkatan ini tidak terlalu besar karena peserta didik masih banyak main dengan permainan sendiri dalam pembelajaran yang menerapkan pendekatan taktis dan gaya mengajar tugas (pratice style). Peningkatan pada siklus 1 tindakan 1 ini terjadi karena ketika pembelajaran berlangsung siswa melakukan keputusan yang diambil, melaksanakan keterampilan dan dukungan.

Peningkatan keterampilan bermain siswa dalam pembelajaran pada siklus 1 tindakan 2 ini sudah lebih baik, karena siswa sudah mengerti dengan diterapkannya pendekatan taktis dan gaya mengajar tugas (pratice style) dalam proses pembelajaran berlangsung sehingga siswa sudah mulai terlihat saling berinteraksi dengan temannya dan lebih aktif dalam proses pembelajaran berlangsung, selain itu keterampilan bermain futsal siswa juga menjadi lebih baik.

Hasil pendekatan taktis dan gaya mengajar tugas (pratice style) dalam pembelajaran futsal pada siklus 1 tindakan 2

Dengan menggunakan pendekatan taktis dan gaya mengajar tugas (practice styles) dalam pembelajaran permainan futsal berpengaruh positif terhadap aspek jasmani peserta didik, namun juga dapat berpengaruh terhadap meningkatnya keterampilan bermain siswa yang dibangun oleh masing-masing individu. Dapat dilihat dalam siklus 1 tindakan 2 ini meningkat hasil keterampilan bermain peserta didik dari hasil siklus 1 tindakan 1 presentase nilai keterampilan bermain bermain peserta didik yaitu $46 \%$ dapat meningkat menjadi $56 \%$, memang peningkatan ini tidak terlalu besar karena peserta didik masih asik dengan permainan mereka sendiri dalam pembelajaran yang menerapkan pendekatan taktis dan gaya mengajar tugas (pratice style). Peningkatan pada siklus 1 tindakan 2 ini terjadi karena ketika pembelajaran berlangsung siswa melakukan keputusan yang diambil, melaksanakan keterampilan dan dukungan.

\section{Hasil Pendekatan Taktis dan Gaya Mengajar Tugas dalam Pembelajaran Futsal pada Siklus 1 Tindakan 2}

Dengan menggunakan pendekatan taktis dan gaya mengajar tugas dalam pembelajaran permainan futsal berpengaruh positif terhadap aspek jasmani peserta didik, namun juga dapat berpengaruh terhadap meningkatnya keterampilan bermain siswa yang dibangun oleh masingmasing individu. Dapat dilihat dalam siklus 2 
tindakan 1 ini meningkat hasil komponen penampilan bermain peserta didik dari hasil siklus 1 tindakan 2 presentase nilai komponen penampilan bermain peserta didik yaitu 56\% dapat meningkat menjadi $65 \%$, memang peningkatan ini sudah lumayan karena peserta didik sudah kondusif dan merasa senang dengan pembelajaran permainan futsal dalam pembelajaran yang menerapkan pendekatan taktis dan gaya mengajar tugas (pratice style). Peningkatan pada siklus 2 tindakan 1 ini terjadi karena ketika pembelajaran berlangsung siswa melakukan keputusan yang diambil, melaksanakan keterampilan dan dukungan.

Peningkatan keterampilan bermain bermain siswa dalam pembelajaran pada siklus 2 tindakan 1 ini sudah lebih baik, karena siswa sudah mengerti dengan diterapkannya pendekatan taktis dan gaya mengajar tugas (pratice style) dalam proses pembelajaran berlangsung sehingga siswa sudah mulai terlihat lebih aktif dalam proses pembelajaran berlangsung, selain itu keterampilan bermain futsal siswa juga menjadi lebih baik.

3. Hasil Pendekatan Taktis dan Gaya Mengajar Tugas dalam Pembelajaran Futsal pada Siklus 2 Tindakan 1

Dengan menggunakan pendekatan taktis dan gaya mengajar tugas dalam pembelajaran permainan futsal berpengaruh positif terhadap aspek jasmani peserta didik, namun juga dapat berpengaruh terhadap meningkatnya keterampilan bermain siswa yang dibangun oleh masingmasing individu. Dapat dilihat dalam siklus 2 tindakan 1 ini meningkat hasil keterampilan bermain peserta didik dari hasil siklus 2 tindakan 2 presentase nilai keterampilan bermain peserta didik yaitu $65 \%$ dapat meningkat men- jadi 81\%, memang peningkatan ini sudah baik karena peserta didik sudah kondusif dan merasa senang ketika pembelajaran permainan futsal dalam pembelajaran yang menerapkan pendekatan taktis dan gaya mengajar tugas (pratice style). Peningkatan pada siklus 2 tindakan 2 ini terjadi karena ketika pembelajaran berlangsung siswa melakukan keputusan yang diambil, melaksanakan keterampilan dan dukungan.

Peningkatan keterampilan bermain siswa dalam pembelajaran pada siklus 2 tindakan 1 ini sudah lebih baik, karena siswa sudah mengerti dengan diterapkannya pendekatan taktis dan gaya mengajar tugas (pratice style) dalam proses pembelajaran berlangsung sehingga siswa sudah mulai terlihat lebih aktif dalam proses pembelajaran berlangsung, selain itu keterampilan bermain futsal siswa juga menjadi lebih baik.

\section{Hasil Pendekatan Taktis dan Gaya Mengajar Tugas dalam Pembelajaran Futsal pada Siklus 2 Tindakan 2}

Dengan menggunakan pendekatan taktis dan gaya mengajar tugas dalam pembelajaran permainan futsal berpengaruh positif terhadap aspek jasmani peserta didik, namun juga dapat berpengaruh terhadap meningkatnya keterampilan bermain siswa yang dibangun oleh masingmasing individu. Dapat dilihat dalam siklus 2 tindakan 1 ini meningkat hasil keterampilan bermain peserta didik dari hasil siklus 2 tindakan 2 presentase nilai keterampilan bermain peserta didik yaitu $65 \%$ dapat meningkat menjadi $81 \%$, memang peningkatan ini sudah baik karena peserta didik sudah kondusif dan merasa senang ketika pembelajaran permainan futsal dalam pembelajaran yang menerapkan pendekatan taktis dan gaya mengajar tugas (pratice 
style). Peningkatan pada siklus 2 tindakan 2 ini terjadi karena ketika pembelajaran berlangsung siswa melakukan keputusan yang diambil, melaksanakan keterampilan dan dukungan.

Peningkatan keterampilan bermain siswa dalam pembelajaran pada siklus 2 tindakan 1 ini sudah lebih baik, karena siswa sudah mengerti dengan diterapkannya pendekatan taktis dan gaya mengajar tugas (pratice style) dalam proses pembelajaran berlangsung sehingga siswa sudah mulai terlihat lebih aktif dalam proses pembelajaran berlangsung, selain itu keterampilan bermain futsal siswa juga menjadi lebih baik.

\section{KESIMPULAN}

Penerapan pendekatan taktis dan gaya mengajar tugas (practice style) dalam pembelajaran futsal mampu mengembangkan nilai keterampilan bermain bermain peserta didik

\section{DAFTAR PUSTAKA}

Mitchell, S. A., Oslin, J. L., \& Griffin, L. L. (2003). Sport foundations for elementary physical education: A tactical games approach. Human Kinetics, PO Box 5076, Champaign, IL 61825-5076 (ISBN: 0-7360-3851-5, \$23).

Mosston, M., \& Ashworth, S. (1990). The Spectrum of Teaching Styles. From Command to Discovery. Longman, Inc., 95 Church St., White Plains, NY 10601-1505.

Permendikbud, R. I. (2014). Peraturan Menteri Pendidikan dan Kebudayaan Republik Indonesia Nomor 137 Tahun 2014 Tentang Standar Nasional Pendidikan Anak Usia Dini. Jakarta: Mendiknas.

Sucipto, (2015). Pembelajaran Permainan Futsal (Implementasi Pendekatan Taktis). Bandung

Sucipto, S. The Implementation of Tactical Approach on Students' Enjoyment in Play- ing Football in Junior High School. JURNAL PENDIDIKAN JASMANI DAN OLAHRAGA, 4(1), 14-20.

Sumpena, A. (2017). Pengaruh Model Pembelajaran Personal (Personal Models) Terhadap Kepercayaan Diri Dan Hasil Belajar Bermain Futsal Siswa. Jurnal Pendidikan Jasmani Dan Olahraga, 2 (1), 1-9. 